\title{
Correction: Haddad, J.G., et al. Doratoxylon apetalum, an Indigenous Medicinal Plant from Mascarene Islands, Is a Potent Inhibitor of Zika and Dengue Virus Infection in Human Cells Int. J. Mol. Sci. 2019, 20, 2382
}

\author{
Juliano G. Haddad ${ }^{1}$, Andrea Cristine Koishi ${ }^{2}$, Arnaud Gaudry ${ }^{3}$, \\ Claudia Nunes Duarte dos Santos ${ }^{2}$, Wildriss Viranaicken ${ }^{1}\left(\mathbb{D}\right.$, Philippe Desprès ${ }^{1}$ (D) and \\ Chaker El Kalamouni ${ }^{1, *(D)}$ \\ 1 Université de la Réunion, INSERM U1187, CNRS UMR 9192, IRD UMR 249, Unité Mixte Processus \\ Infectieux en Milieu Insulaire Tropical, Plateforme Technologique CYROI, \\ 94791 Sainte Clotilde, La Réunion, France; juliano.haddad@univ-reunion.fr (J.G.H.); \\ wildriss.viranaicken@univ-reunion.fr (W.V.); philippe.despres@univ-reunion.fr (P.D.) \\ 2 Laboratorio de Virologia Molecular, Instituto Carlos Chagas, ICC/FIOCRUZ/PR, Curitiba, \\ Parana 81350-010, Brazil; ackoishi@gmail.com (A.C.K.); clsantos@fiocruz.br (C.N.D.d.S.) \\ 3 Bioactive Natural Products Unit, School of Pharmaceutical Sciences, EPGL, University of Geneva, \\ Rue Michel-Servet 1, CH-1211 Geneva, Switzerland; Arnaud.gaudry@unige.ch \\ * Correspondence: chaker.el-kalamouni@univ-reunion.fr; Tel.: +262-262-938822
}

Received: 13 October 2020; Accepted: 19 October 2020; Published: 22 October 2020

The author wishes to make the following correction to this paper [1]: In the Materials and Methods section, paragraph 3.2: Voucher specimen (RUN-055E) should be Voucher specimen (T-1097). The mistake was generated during final editing following peer-review. The mistake did not affect the review process. Our correction does not change the conclusions of this manuscript.

The authors would like to apologize for any inconvenience caused to the readers by these changes.

Conflicts of Interest: The authors declare no conflict of interest.

\section{Reference}

1. Haddad, J.G.; Koishi, A.C.; Gaudry, A.; Nunes Duarte dos Santos, C.; Viranaicken, W.; Desprès, P.; El Kalamouni, C. Doratoxylon apetalum, an Indigenous Medicinal Plant from Mascarene Islands, Is a Potent Inhibitor of Zika and Dengue Virus Infection in Human Cells. Int. J. Mol. Sci. 2019, 20, 2382. [CrossRef] [PubMed]

Publisher's Note: MDPI stays neutral with regard to jurisdictional claims in published maps and institutional affiliations.

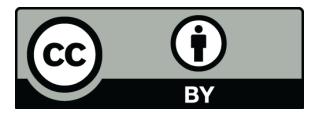

(C) 2020 by the authors. Licensee MDPI, Basel, Switzerland. This article is an open access article distributed under the terms and conditions of the Creative Commons Attribution (CC BY) license (http://creativecommons.org/licenses/by/4.0/). 